\title{
Sickness absence in diabetic employees at a large engineering factory
}

\author{
C J M Poole, D Gibbons, I A Calvert
}

\begin{abstract}
It is not known whether employees who have diabetes mellitus lose more time from work due to sickness than non-diabetic employees. A study was undertaken to compare sickness absence in 91 diabetic with 91 non-diabetic employees matched for sex, age, and occupation. Although sickness absence was greater in the diabetic group this was not significant. Mean sickness absence for the diabetic employees and controls was $32 v 20$ days/year ( $95 \%$ confidence interval -5 to 29 days). Because of the large variability in sickness absence in both diabetic and non-diabetic employees, a study of this size is probably not sufficiently powerful to detect a difference.
\end{abstract}

(Occup Environ Med 1994;51:299-301)

Studies have been done to compare sickness absence in diabetic and non-diabetic employees, ${ }^{1-7}$ but different approaches have been used, each with its own limitations. Some of the published studies involved people attending a hospital or community diabetic clinic, ${ }^{5-7}$ which would bias the sample towards those with severe or complicated disease, of whom only $50 \%-60 \%$ were in employment. Others have used questionnaires with response rates as low as $53 \%,{ }^{7}$ or asked the diabetic people to select their own controls, ${ }^{7}$ or asked the personnel department at their place of work to select the controls. ${ }^{46}$ One study supplemented the number of subjects by recruiting from the company's sickness absence records, ${ }^{4}$ thereby biasing the study towards those who had lost time. Some studies have not shown statistical analysis of their data. ${ }^{34}$ It is still not clear, therefore, whether diabetic workers have more or less sickness absence than non-diabetic workers, and a request has been made for more information about diabetes and employment, and for surveys of sickness absence to be carried out in this country. ${ }^{8}$

People with diabetes may be discriminated against when seeking work, either through ignorance about the nature of the condition, or in the belief that they will lose more time from work than someone without diabetes, or that their condition will prevent them from working shifts, working at heights, and so on. Furthermore, attempts to calculate the cost of diabetes to the community have included calculations based on estimated levels of sickness absence up to three times that of the non-diabetic population. ${ }^{9}$
A cross sectional study was therefore undertaken to compare sickness absence between diabetic and non-diabetic employees, matched for sex, age, and occupation, in a large engineering factory with a well established occupational health department.

\section{Employees and methods}

Ninety one diabetic employees (30 insulin treated) were identified from a diagnostic index in the occupational health department of a large engineering factory with a workforce of about 15000 on a single site. The index was compiled over several years from employees who reported their condition either at the health assessment before employment, voluntarily at a later date, or as a result of the diagnosis being made by the occupational health staff. The company's policy on the recruitment of diabetic employees has been consistent for many years. That is, those treated with insulin were given day only jobs where possible, whereas those recruited to work shifts would be expected to adjust their insulin regimen accordingly.

The diabetic employees were divided into those born before 1940 , between 1940 and 1950 , and after 1950 . Controls were found by systematically working through a computer generated alphabetical list of all employees with basic personal details, until each case had a control matched for sex, age, occupation, and grade (hourly paid, staff, or managerial grade).

Sickness absence was taken from computerised personnel records for the period 1986-91. Diabetic employees or controls who had worked for the company for less than five years, or who left during this time, were excluded. The total duration of absences, the average duration of each episode of absence, the number of spells of absence, and the reasons for absence during the five years were recorded for both diabetic employees and their controls.

Statistical analysis was by one tailed Wilcoxon's matched pairs and one tailed paired $t$ tests as appropriate.

\section{Results}

All 91 diabetic employees and 91 controls were men. The mean (range) age of the diabetic employees was $49(26-60)$ and that of the controls was $47(23-62)$ years. 
Table 1 Duration of time off (days/year)

\begin{tabular}{lllll}
\hline & $n$ & Median & IQR & Mean (SD) \\
\hline $\begin{array}{l}\text { Born before 1940: } \\
\quad \text { Diabetic men }\end{array}$ & 55 & 11 & 26 & $35(71)$ \\
$\quad$ Controls & 55 & 14 & 25 & $29(55)$ \\
$\begin{array}{l}\text { Born 1940-50: } \\
\quad \text { Diabetic men }\end{array}$ & 21 & $8 \cdot 6$ & 20 & $27(60)$ \\
$\quad$ Controls & 21 & 1.0 & $8 \cdot 8$ & $7 \cdot 0(12)$ \\
$\begin{array}{l}\text { Born after 1950: } \\
\quad \text { Diabetic men }\end{array}$ & 15 & 6.4 & 24 & $27(49)$ \\
$\quad$ Controls & 15 & $1 \cdot 4$ & $5 \cdot 4$ & $3.4(4 \cdot 0)$ \\
$\begin{array}{l}\text { All ages: } \\
\quad \text { Diabetic men }\end{array}$ & 91 & $9 \cdot 4$ & 25 & $32(65)$ \\
$\quad$ Controls & 91 & 5.6 & 21 & $20(45)$ \\
\hline$\quad$ IQR & & & &
\end{tabular}

$\mathrm{IQR}=$ interquartile range.

Table 1 shows the duration of absence in days for all ages as well as the duration of absence stratified by age for diabetic employees and controls. The mean time off work was $32 v 20$ days/year respectively (95\% confidence interval $(95 \% \mathrm{CI})-5.0$ to 29 days). The median time off sick for diabetic employees and controls was $9.4 v 5.6$ days/year $(Z=$ $-1.53, p=0.06)$. The failure to reach significance may be because there is no difference in sickness absence, but given the large apparent difference in mean sickness absence (12 days), it is possible that the study was insufficiently powerful to detect a difference because of the large variability in time taken off work (from 0 to 365 days/year) by both diabetic men and controls.

Table 2 shows the duration of each spell and number of spells of absence over the five year period for all ages and stratified by age for diabetic employees and controls. The median duration of each period of absence was $12 v 9.3$ days respectively $(Z=-1.51, \mathrm{p}=$ 0.07 ), but for those born between 1940 and 1950 the median duration of absence was longer in the diabetic employees, $11 v 4.0$ days $(Z=-1 \cdot 88, \mathrm{p}=0.03)$. Although the median number of spells of absence was similar for all age groups in both diabetic employees and controls, in those born after 1950 the median number of spells of absence was significantly more in the diabetic employees $(3.0$ $v 1.0 ; Z=-1.80, \mathrm{p}=0.04$ ), due to three subjects having long and repeated absences because of knee problems.

The mean numbers of days lost from work by all diabetic employees and controls/year, according to diagnosis on the sick note, were

Table 2 Duration of and number of spells of absence

\begin{tabular}{|c|c|c|c|c|c|}
\hline & \multicolumn{3}{|c|}{ Duration of each spell of absence (days) } & \multicolumn{2}{|c|}{ No of spells of absence (1986-91) } \\
\hline & $n$ & Median & $I Q R$ & Median & $I Q R$ \\
\hline $\begin{array}{l}\text { Born before 1940: } \\
\text { Diabetic men } \\
\text { Controls }\end{array}$ & $\begin{array}{l}55 \\
55\end{array}$ & $\begin{array}{l}13 \\
13\end{array}$ & $\begin{array}{l}23 \\
30\end{array}$ & $\begin{array}{l}2 \cdot 0 \\
3 \cdot 0\end{array}$ & $\begin{array}{l}5 \cdot 0 \\
4.0\end{array}$ \\
\hline $\begin{array}{l}\text { Born 1940-50: } \\
\text { Diabetic men } \\
\text { Controls }\end{array}$ & $\begin{array}{l}21 \\
21\end{array}$ & 11 & $\begin{array}{c}19 \\
8 \cdot 7\end{array}$ & $\begin{array}{l}4 \cdot 0 \\
2 \cdot 0\end{array}$ & $\begin{array}{l}5 \cdot 0 \\
4 \cdot 0\end{array}$ \\
\hline $\begin{array}{l}\text { Born after 1950: } \\
\text { Diabetic men } \\
\text { Controls }\end{array}$ & $\begin{array}{l}15 \\
15\end{array}$ & $\begin{array}{l}9 \cdot 3 \\
6\end{array}$ & $\begin{array}{r}20 \\
9\end{array}$ & $\begin{array}{l}3 \cdot 0 \\
1 \cdot 0^{\star}\end{array}$ & $\begin{array}{l}5 \cdot 0 \\
2 \cdot 0\end{array}$ \\
\hline $\begin{array}{l}\text { All ages: } \\
\text { Diabetic men } \\
\text { Controls }\end{array}$ & $\begin{array}{l}91 \\
91\end{array}$ & $\begin{array}{c}12 \\
9 \cdot 3\end{array}$ & $\begin{array}{l}22 \\
22\end{array}$ & $\begin{array}{l}3 \cdot 0 \\
2 \cdot 0\end{array}$ & $\begin{array}{l}5 \cdot 0 \\
3.0\end{array}$ \\
\hline
\end{tabular}

respectively $838 v 382$ for diabetes or cardiovascular disease, $420 v 321$ for infections, 423 $v 292$ for injuries, and $44 v 411$ for miscellaneous causes, mainly.psychological ill health.

\section{Discussion}

This study suggests that diabetic employees may have more sickness absence than nondiabetic employees. Although the differences did not reach significance, there was a consistent trend within subgroups towards those with diabetes losing more time from work. The mean number of days lost/year by diabetic employees was 32 . This is higher than in previous studies, ${ }^{45}$ possibly in part due to the culture of the organisation, in which the work is paced and monotonous and traditionally associated with levels of sickness absence higher than the industrial average. Interestingly four of the diabetic and one of the non-diabetic employees had been absent from work for more than four years. This was because it was the company's policy not to end the contracts of employment of employees who were not in receipt of company sick pay. Conversely, eight diabetic and four nondiabetic employees had lost no time from work due to sickness during the five year period of study. The increased number of days lost because of cardiovascular disease and infections in the diabetic group is not surprising, but the low number of days lost with psychological illness is worthy of further study.

The 91 diabetic men in this study represent $0.6 \%$ of the workforce, which is less than the often quoted prevalence for diabetes of $1 \%$ $2 \%$ in the general population. This difference is not surprising as the figure for the general population includes those with diabetes who are too ill or too old for employment. Furthermore there may have been a bias towards recruiting non-diabetic employees as most of the hourly paid jobs involved working shifts and diabetic workers have traditionally been discouraged from working shifts on the grounds that this would prevent good glycaemic control.

A recent study has shown that insulin treated diabetic employees can work shifts without compromising the control of their diabetes, although better education and more flexibility in the way in which the insulin is taken is needed. ${ }^{10}$ For example, when insulin is taken twice daily the injections should be advanced for early shifts, delayed for late shifts, and reversed for night shifts, so that the larger dose is taken before the night shift.

It is possible that the sample of diabetic employees in this study was biased towards those with a more severe form of diabetes, as they presumably would have come more readily to the attention of the occupational health department than those with less severe disease but sickness absence records were not used to recruit subjects for the study. Also, it is likely that some diabetic employees were not known to the occupational health department. If it is assumed that the variables from our data are 
representative of diabetic employees in general, then for a similar study to have an $80 \%$ chance of reaching significance for the mean number of days taken off per year, we calculate that there would need to be over 340 diabetic employees in the study population.

1 Nasr ANM, Block DL, Magnuson HJ. Absenteeism experience in a group of employed diabetics. $f$ Occup Med 1966;8:621-5.

2 Pell S, D'Alonzo CA. Sickness absenteeism in employed diabetics. Am f Public Health 1967;57:253-60.
3 Moore RH, Buschbom MA. Work absenteeism in diabetes. Diabetes 1974;23:957-61.

4 Welch RA. Employment of diabetics in a Post Office region. f Occup Med 1986;36:80-5.

5 Songer TJ, LaPorte RE, Dorman JS, et al. Employment spectrum of IDDM. Diabetes Care 1989;12:615-22.

6 Waclawski ER. Sickness absence among insulin-treated diabetic employees. Diabet Med 1990;7:41-4.

7 Robinson N, Yateman NA, Protopapa LE, Bush L Employment problems and diabetes. Diabet Med 1990;7:16-22.

8 Greenwood RH, Raffle PAB, Diabetes mellitus. In: Edwards SC, McCallum RI, Taylor PJ, eds. Fitness to work: Medical aspects. Oxford: Oxford University Press, work: Medical as

9 Gerard K, Donaldson C, Maynard AK. The cost of diabetes. Diabet Med 1989;6:164-70.

10 Poole CJM, Wright AD, Nattrass $M$. Control of diabetes mellitus in shift workers. Br F Ind Med 1992;49:513-5. 